\title{
Analisis Kinerja Karyawan Dalam Meningkatkan Prestasi Kerja di PT Tunas Dwipa Matra Motor Honda Manado
}

\author{
Westepina Sanra Wahe. \\ Sontje M Sumayku, \\ Ventje Tatimu \\ Program Studi Administrasi Bisnis, Jurusan ilmu Administrasi, \\ Fakultas Ilmu Sosial dan pPolitik Universitas Sam Ratulangi \\ Email ; westepinawahe@gmail.com
}

\begin{abstract}
The purpose of this study is to determine the performance of employees ini improving work performance and how an employee can achieve well. Factors that make a company grow, and progress is not only determined by capital and a strong business strategy, but also from the factors of employees or $(H R)$ is great. Human resources $(H R)$ is one of the most important factors that cannot even be separated from an organization, both institutions and companies. In essence, human resources in the form of humans are employed in an organization as a driver, thinker and planner to achieve organizational goals. The strategic role of PT Tunas Dwipa Honda Motor Matra Manado is as an organization or company influenced by ineffective employee performance, so that in a company $H R$ is the main part in processing for achieving maximum results. The research method used is a descriptive qualitative research method that focuses on understanding social phenomena that occur in society. The samples taken are all existing permanent employees. And from the interview results obtained that performance shows good work performance, because of that the results achieved and desired by everyone in the work so that the company's goals can be said to successfully meet the target company.
\end{abstract}

\section{Keywords: Employee Performance}

\section{Pendahuluan}

Faktor yang membuat perusahaan menjadi berkembang, dan maju bukan hanya ditentukan oleh modal serta strategi bisnis yang kuat saja, melainkan juga dari faktor karyawan atau (SDM) yang hebat. Dengan memiliki SDM yang hebat, pencapaian target yang diinginkan perusahaan bukan hal yang mustahil untuk dicapai. Hal ini akan sesuai dengan visi dan misi perusahaan, dan tentunya akan memuat perusahaan akan lebih jauh ber- kembang. Sumber daya manusia (SDM) adalah salah satu faktor yang sangat penting bahkan tidak dapat dilepaskan dari sebuah organisasi, baik institusi maupun perusahaan. SDM juga merupakan kunci yang menentukan perkembangan perusahaan. Pada hakikatnya, SDM berupa manusia yang dipekerjakan di sebuah organisasi sebagai penggerak, pemikir dan perencanaan untuk mencapai tujuan organisasi. Harus diingat bahwa dalam satu organisasi perusahaan, aspek manusia yang 
berkemampuan, ber-ketrampilan, bertanggung-jawab sebagai karyawan merupakan sebagai aset perusahaan yang sangat berharga bagi kelangsungan hidup perusahaan. Kinerja karyawan tidak akan optimal apa bila hanya mengandalkan mesin produksi tanpa memperhatikan aspek manusianya.

Karyawan adalah SDM atau penduduk yang bekerja di suatu institusi baik pemerintah maupun swasta (bisnis). Sumber daya manusia adalah potensi yang menjadi motor penggerak organisasi/ perusahaan. Kemudian oleh Wirawan yang menjelaskan bahwa sumber daya manusia merupakan sumber daya yang digunakan untuk menggerakkan sumber daya lain untuk mencapai tujuan organisasi. Aspekaspek ini adalah sebagai perangsang karyawan terhadap produktifitas Kinerja Karyawan

Salah satu faktor penentu keberhasilan perusahaan adalah kinerja dan produktifitas karyawan. Analisis kinerja karyawan di PT Tunas Dwipa Diler Motor Honda Manado, kinerja merupakan suatu penilaian khusus di mana suatu perusahaan harus memiliki suatu prestasi yang benarbenar mampu bersaing dengan perusahaan lain.

Kinerja adalah salah satu ukuran yang biasa dipakai oleh banyak perusahaan dalam menilai karyawannya. Selain dari penilaian yang mengunakan kinerja, karyawan juga dapat dinilai dari tingkat kehadiran atau absensi, dedikasi dalam mengerjakan tugas yang diemban, loyalitas pada perusahaan dan pekerjaan-nya dan faktor-faktor yang lain. Akan tetapi dari banyak kriteria yang dapat dipergunakan dalam penilaian karyawan, kinerja merupakan hal yang paling banyak di pakai sebagai tolak untuk menentukan baik atau tidaknya pekerjaan dari karyawan di perusahaan tersebut. Secara sederhana kinerja adalah ukuran seberapa baik pencapaian suatu pekerjaan yang dibebankan perusahaan kepada karyawannya (Syahyuni, 2018) .

Menurut Wibowo (2013) Kinerja dipandang sebagai proses pekerjaan dimana kinerja merupakan suatu proses bagaimana pekerjaan berlangsung untuk mencapai hasil kerja. Menurut Anwar, (2013) Kinerja (prestasi kerja) adalah hasil kerja secara kualitas dan kuantitas yang dicapai oleh seorang pegawai dalam melaksanakan tugasnya sesuai dengan tanggung jawab yang diberikan kepadanya.

Membahas mengenai motivasi kerja, tidak dapat terlepas dari pembahasan mengenai prestasi kerja. Karena motivasi kerja merupakan bagian yang terpenting dari tingkah laku kerja tersebut. Prestasi kerja dapat diartikan sebagai hasil yang dicapai seseorang menurut ukuran yang 
berlaku untuk pekerjaan yang bersangkutan. prestasi kerja adalah suatu hasil kerja yang dicapai seseorang dalam melaksanakan tugas-tugas yang dibebankan kepadanya yang didasarkan atas kecakapan, pengalaman dan kesungguhan serta waktu. prestasi kerja juga di artikan sebagai kesuksesan seseorang dalam melaksanakan suatu pekerjaan.

Ruang lingkup masalah penelitian ini adalah kinerja karyawan yang tidak optimal, dan ketidaktepatan waktu, mengakibatkan menurunnya prestasi kerja karyawan di PT Tunas Dwipa Matra Motor Honda Manado. Sebagaimana kinerja suatu karyawan merupakan alat untuk pencapaian tujuan suatu perusahaan. Karena itu bagaimana kinerja suatu perusahaan bisa mampu bersaing dengan perusahaan lain sehingga tujuan perusahaan bisa tercapai. Kinerja dan prestasi karyawan merupakan tujuan utama untuk mencapai tujuan. Sebab itu dalam sebuah organisasi/perusahaan karyawan harus benar- benar mampu melakukan tugas dan tanggung jawab yang diberikan manajer kepadanya. Berdasarkan latar belakang pemikiran tersebut maka penulis tertarik dengan mengambil judul pokok bahasan penelitian mengenai "Analisis Kinerja Karyawan Dalam Meningkatkan Prestasi Kerja. Di PT Tunas Dwipa Matra Motor Honda Manado"

\section{Kinerja Karyawan}

Menurut Wirawan (2009) konsep kinerja merupakan singkatan dari kinetika energi kerja yang pada dalam bahasa Inggris adalah performance. Kinerja setiap orang juga tergantung pada setiap perorganisasian, penyediaan sarana dan prasarana kerja, pemilihan teknologi, kenyamanan lingkungan kerja serta kondisi dan syarat kerja.

\section{Deskripsi Variabel Kinerja Karyawan}

Variabel kinerja karyawan diukur oleh tiga indikator yaitu Kuantitas dari hasil, kualitas dari hasil, dan ketetapan waktu dari hasil. Setiap proses kerja yang dilakukan seorang bermuara pada hasil. Karna itu hasil kerja secara kualitatif dari karyawan yang menjadi responden dari penelitian ini. Menurut Miner (1990) dalam karisma (2011) kualitas yang dihasilkan berkenan dengan berapa jumlah produk atau jasa yang di hasilkan.

\section{Hipotesis}

Berdasarkan kerangka pemikiran maka dapat dirumuskan hipotesis penelitian ini adalah: kinerja dan prestasi karyawan berpengaruh terhadap keputusan pembeli di PT Tunas Dwipa Matra Motor Honda Manado. 


\section{Metode Penelitian}

Jenis metode penelitian yang di gunakan adalah metode kualitatif deskriptif penelitian yang berfokus pada pemahaman terhadap fenomena sosial yang terjadi di masyarakat. Pada metode penelitian ini, peneliti menggunakan perspektif dari partisipan sebagai gambaran yang diutamakan dalam memperoleh hasil penelitian. Penelitian kualitatif deskriptif tujuannya mencakup informasi tentang fenomena utama yang sedang dieksplorasi dalam suatu penelitian, partisipan penelitian, dan lokasi suatu penelitian. Pada penelitian kualitatif variabel penelitian merupakan hal penting yang harus sudah didefinisikan dan ditentukan sejak dilatar belakang. Penelitian kualitatif juga dapat menyatakan rancangan penelitian yang dipilih. Penelitian ini dilakukan pada PT Tunas Dwipa Matra motor Honda Manado. Penelitian ini dilakukan pada bulan april 2019.

Instrumen utama dalam penelitian kualitatif adalah penelitian sendiri. Dan sumber data utama dalam penelitian kualitatif ialah kata-kata, dan tindakan; selebihnya adalah data tambahan seperti dokumen dan lain-lain.

\section{Hasil Penelitian dan Pembahasan}

PT. Tunas Dwipa Matra adalah perusahaan yang bergerak di perdagangan umum, termasuk penjualan dan pembelian kendaraan bermotor dan suku cadang asli sepeda motor yang bermerek Honda. Penjualan suku cadang asli Honda dan pelayanan jasa bagi pemilik kendaraan sepeda motor Honda. Sejak berdiri nya perusahaan PT. Tunas Dwipa Matra cabang kota manado yang telah membeli saham perusahaan dari PT. Andico Karya Prima Pada tahun 2013.

Tabel 1 Rincian Product Motor Honda yang Dijual PT. Tunas Dwipa Matra Cabang Kota Manado.

\begin{tabular}{lr}
\hline Series Motor & Tipe Motor \\
\hline HONDA BEAT & HLO \\
& HMO \\
& HKO \\
GWA \\
\hline HONDA SCOOPY & HCA \\
& HCO \\
& HAI \\
\hline HONDA VARIO & HBI \\
\hline HONDA SUPRA X & GZI \\
& FI \\
& GTR \\
\hline HONDA REVO & REVO FIT \\
& REVO CW \\
HONDA SUPER CBU & REVO X \\
\hline
\end{tabular}

Sistem penjualan yang dilakukan oleh PT. Tunas Dwipa Matra kini mempunyai dua cara untuk melakukan transaksi yakni pembayaran secara tunai (Cash) dan pembayaran secara angsuran (Kredit). Pembayaran yang melakukan Honda yaitu Federal International Finance (FIF), Mega Central Finance (MCF), PT. Wahana ottomitra Multiartha Tbk (WOM Finance), OTO, dan Adira.

Kebutuhan dan selera konsumen mempunyai selera dan gaya hidup yang 
berbeda-beda dalam memilih alat transportasi atau kendaraan sepeda motor. Dengan memahami dan mengetahui apa yang dibutuhkan konsumen itu sendiri, akan membantu sebuah perusahaan untuk dapat menciptakan pasar yang lebih luas lagi sesuai dengan kebutuhan konsumen. Yang dimana pada PT.Tunas Dwipa Matra kota Manado kini perusahaan yang berjalan dalam bidang otomotif menjual berbagai macam jenis tipe motor yang dibutuhkan oleh konsumen, yakni berbagai jenis motor dengan desain dan tipe motor yang berbeda-beda. Dalam penelitian ini, Peneliti melakukan analisis terhadap dimensi gaya hidup yang terdiri dari activies (Aktifitas). Interst (Minat), opinions (opini) kinerja, Prestasi yang sesuai yang ada di lapangan. Dengan itu maka peneliti mengajukan pertanyaan-pertanyaan melalui wawancara kepada 8 pegawai tetap.

Dalam melakukan kegiatan dan aktivitas kehidupan sehari-hari para konsumen, khususnya konsumen memilih berbagai jenis motor yang pantas dan yang sesuai dengan selera dan kebutuhan konsumen itu sendiri. Adapun langka yang dapat dilakukan oleh PT. Tunas Dwipa Matra Cabang Manado menawarkan berbagai jenis tipe motor khususnya pada merek honda dengan berbagai jenis motor yang pantas dan sesuai dengan kebutuhan serta selera konsumen. Dalam hal ini peneliti melakukan penelitian terhadap kinerja karyawan dalam meningkatkan prestasi kerja.

Minat konsumen dalam memilih suatu produk atau barang yang diinginkan untuk memenuhi kebutuhannya berbedabeda, minat konsumen dalam memilih suatu produk akan dilihat dari kebutuhan sehari-hari itu sendiri terlebih dahulu dengan mengetahui apa yang mereka anggap penting. Minat konsumen mengacu pada kesukaan atau ketertarikan terhadap suatu produk yang ditawarkan oleh perusahaan. Adapun langka yang dapat dilakukan oleh PT. Tunas Dwipa Matra Manado yakni menawarkan berbagai jenis tipe motor khususnya pada merek honda dengan berbagai desain motor yang berbeda-beda serta varian warna yang beraneka ragam yang dapat dipilih sesuai dengan selera dan kebutuhan konsumen.

Opini seseorang yakni mempunyai pandangan yang berbeda terhadap suatu objek atau produk yang akan mereka pilih. Oleh karena itu opini setiap konsumen dalam memilih suatu barang atau produk memiliki presepsi dan perasaan yang berbeda terhadap suatu barang yang mereka lihat, dan tentunya opini yang menyangkut presepsi terhadap suatu barang yang akan dipilih oleh seorang konsumen memiliki opini yang sesuai dengan kebutuhan seharihari yang berhubungan dengan dunia 
sekitarnya maupun lingkungannya. Seperti dalam memilih suatu alat transportasi konsumen memiliki opini yang sesuai harapan dan keinginannya, dengan persepsi yang berbeda terhadap motor yang dilihatnya untuk dapat dijadikan sebagai alat transportasi yang dapat dimiliki.

Salah satunya persepsi konsumen dalam melihat produk sepeda motor Honda yang mempunyai pandangan dan juga persepsi yang berbeda. Konsumen dalam memiliki produk sepeda motor tentunya ingin memenuhi gaya hidup yang sesuai dengan dirinya, dengan memilih sepeda motor honda apakah sepeda motor honda merupakan salah satu sepeda motor yang sedang populer pada saat itu sehingga konsumen memilih honda ataukah konsumen lebih memilih produk lain.

Sebagaimana telah di sebutkan dalam uraian metodologi penelitian di atas bahwa Tujuan penelitian ini adalah untuk menganalisis bagaimana Kinerja Karyawan dalam meningkatkan Prestasi Kerja di PT Tunas Dwipa Matra Motor Honda Manado. Oleh karna itu untuk menjawab masalah penelitian, maka telah di lakukan pengumpulan data dengan menggunakan teknik-teknik wawancara dan observasi lapangan. Untuk itu peneliti juga melakukan wawancara terhadap konsumen dalam membeli suatu produk motor Honda. Dan menanyakan bagaimana konsumen bisa tertarik dalam membeli suatu produk dari PT. Tunas Dwipa Matra tersebut.

Pendapat Konsumen : konsumen tertarik karena produk merk Honda khususnya yang menjual PT. Tunas Dwipa Matra memiliki kualitasnya yang bagus dan sudah teruji. Sehingga saya sebagai konsumen tertarik dengan merek motor tersebut.

Saya sebagai konsumen tertarik membeli jenis produk motor Honda karna memiliki banyak jenis motor dengan desain dan tipe motor yang berbeda-beda khususnya saya sebagai wanita tertarik dengan tipe motor Matic selain memiliki desain yang oke, motor matic juga mempermuda kaum wanita dalam berkendara.

Karyawan : PT. Tunas Dwipa Matra adalah perusahan yang menjual produk sepeda motor yang memiliki banyak tipe dan gaya yang berbeda. Dalam melakukan satu penjualan tentunya memiliki banyak tantangan karna itu kami sebagai karyawan harus memiliki teknik dalam melakukan pemasaran bagaimana kami sebagai karyawan bisa menarik hati konsumen agar bisa membeli produk kami, kami harus memiliki strategi yang tepat sasaran, karena itu merupakan kunci dalam keberhasilan dari penjualan suatu produk. Salah satu teknik marketing adalah komunikasi yang baik dan produk yang ditawarkan juga 
mempunyai nilai tambah dalah marketing, penguasaan produk yang ditawarkan juga berpengaruh untuk hasil kinerja karyawan. Kinerja karyawan dalam memberikan layanan kepada konsumen menurut Pio et.al. (2015) di wujudkan dalam bentuk memberikan yang terbaik dalam bekerja, melayani konsumen dengan senyum, menolong dengan tulus kepada pelanggan dan rekan kerja, mengutamakan kepentingan dan kepuasan pelanggan.

Dari hasil penjualan di atas maka bisa dilihat bagaimana kinerja karyawan di PT. Tunas Dwipa Matra Motor Honda manado. Peneliti memperoleh hasil dari wawancara denga informasi mengenai kinerja karyawan, perolehan penjualan, dan prestasi yang telah dicapai oleh karyawan. Kinerja karyawan di PT. Tunas Dwipa Matra memiliki tingkat kualitas kerja yang baik, memiliki keterampilan dalam menarik hati pelanggan, memiliki sikap yang baik terhadap konsumen dan sesama karyawan. Perolehan penjualan di PT. Tunas Dwipa Matra Motor Honda Manado pada tahun 2018 di katakan berhasil memenuhi tujuan perusahan dimana masing-masing karyawan mampu menjalankan tugas dan tanggung jawab sesuai denga misi perusahaan. Prestasi kerja di PT. Tunas Dwipa Matra Motor Honda manado di mana penilaian prestasi kerja dimulai dengan membandingkan satu karyawan dengan karyawan yang lain menentukan siapa yang lebih baik, perbandingan ini dilakukan secara keseluruhan. Dari hasil penilaian diatas maka terdapat salah satu karyawan yang memiliki prestasi yang sangat luar biasa dimana dalam satu tahun terakhir karyawan tersebut bisa menjual produk motor dengan capaian 297 dalam setahun. Hasil yang telah dicapai oleh seorang karyawan tersebut menunjukkan prestasi kerja yang sangat luar biasa oleh seorang karyawan.

Oleh karena itu agar mempunyai kinerja yang baik, seorang harus mempunyai keinginan yang tinggi untuk mengerjakan serta mengetahui pekerjaannya. Tanpa mengetahui kegiatan faktor kinerja yang baik tidak akan tercapai. Dengan kata lain kinerja individu dapat ditingkatkan apa bila ada kesesuaian antara pekerja dan kemampuan. Kinerja individu dipengaruhi oleh kepuasan kerja. Kepuasan kerja itu sendiri adalah perasaan individu terhadap pekerjaannya. Perasaan ini berupa suatu hasil penilaian mengenai seberapa jauh pekerjaannya secara keseluruhan mampu memuaskan atau memenuhi kebutuhan.

Pada dasarnya, kinerja merupakan sebuah fungsi dari motivasi dan kemampuan untuk menyelesaikan tugas atau pekerjaan, dimana seorang sepatu-nya memiliki derajat kesediaan dan tingkat 
kemampuan tertentu. Artinya kinerja ditunjukan dalam bentuk perilaku nyata yang ditampilkan setiap orang sebagai prestasi kerja sesuai dengan perannya dalam perusahaan. Kinerja karyawan sangatlah berpengaruh terhadap upaya perusahaan untuk mencapai tujuannya. Oleh karna itulah perusahaan akan berusaha mempekerjakan hanya mereka yang memiliki kinerja yang baik. Maka dari situlah muncul pertanyaan soal bagaimana mengukur kinerja tersebut. Jawabannya dengan melihat penilaian kinerja yakni penilaian prestasi kerja. Sasaran yang dituju dalam penilaian ini adalah kecakapan, kemampuan karyawan dalam melaksanakan suatu pekerjaan atau tugas yang dievaluasi dengan menggunakan tolak ukur tertentu secara objektif dan dilakukan secara berkala.

\section{Pembahasan}

Berdasarkan hasil penelitian dari Analisis kinerja karyawan dalam meningkatkan Prestasi kerja di PT. Tunas Dwipa Matra Motor Honda Manado: dengan menganalisis hasil wawancara bahwa tujuan kinerja karyawan sudah dilakukan dengan baik.

Karena itu dari hasil yang ada maka dapat di bandingkan kinerja dan prestasi karyawan yang benar-benar mampu mencapai hasil yang maksimal yang diberikan oleh perusahaan kepadanya, prestasi di lihat oleh seorang manajer melalui usaha-usaha yang dilakukan oleh karyawan dalam bekerja keras untuk mencapai hasil dan tujuan perusahan.

Dalam penelitian ini yaitu prestasi yang dicapai oleh karyawan dalam melaksanakan tugasnya, untuk mencapai tujuan dalam organisasi maka diperlukan kerja sama, adalah untuk bekerja sama dengan orang lain dalam menyelesaikan suatu tugas dan pekerjaan yang telah ditetapkan, sehingga mencapai daya guna dan hasil guna yang sebesar-besarnya. Dengan menganalisis hasil wawancara tersebut maka prestasi kerja karyawan dikatakan baik, karna dengan hasil saat melakukan penelitian di lapangan masingmasing karyawan bekerja dengan baik dan sesuai dengan harapan perusahaan.

\section{Kesimpulan}

Lewat penelitian yang telah di lakukan dapat disimpulkan bahwa kinerja adalah hasil yang harus dicapai oleh seorang karyawan dalam melaksanakan tugas sesuai dengan tanggung jawab yang diberikan oleh perusahaan kepadanya. Kinerja dan prestasi yang telah dicapai oleh karyawan memiliki tingkat kualitas kerja yang baik, memiliki keterampilan dalam menarik hati pelanggan dan memiliki sikap yang baik terhadap konsumen dan sesama 
karyawan. Penilaian prestasi kerja dimulai dengan membandingkan suatu karyawan dengan karyawan yang lain menentukan siapa yang lebih baik dan yang mampu mencapai hasil yang maksimal. kinerja menunjukan prestasi kerja yang baik, karna itu hasil yang dicapai dan di inginkan oleh semua orang dalam bekerja sehingga tujuan perusahaan bisa dikatakan berhasil memenuhi target perusahaan.

\section{Saran}

Disarankan kepada karyawan PT. Tunas Dwipa Matra Motor Honda Manado untuk lebih semangat dan fokus lagi dalam melaksanakan Tugas dan Tanggung jawab yang di berikan perusahan. Karena itu merupakan suatu kunci keberhasilan dalam suatu pekerjaan. Dan kepada manager untuk terus-menerus memberikan bimbingan, dorongan, dan motivasi dalam bekerja kepada karyawan sehingga karyawan bisa dan mampu memenuhi target perusahaan.

\section{Daftar Pustaka}

Anwar Prabu Mangkunegara. 2013. Manejemen Sumber Daya manusia. remaja Rosda kaarya ,Bandung.

Karisma, H. 2011. Pengertian Kinerja http://hardiyantikarisma. Blog.com.7 Oktober 2011.
Pio, R. J. 2015. Kepemmpinan Spiritual Dimenssi - Dimensi Sumber Daya Manusia Kepel Press.Yogyakarta.

Pio, R.J., Niman,U., Alhabsji,T., dan Hamid,D. (2015) Pengaruh Kepemimpinan Spritual terhadap perilaku etis kualitas kehidupan kerja, kepuasan kerja komitmen organisasional dalam kinerja karyawan. Jurnal Derema, Vol.10, No.1, hal.22-60

Syahyuni Dedy. 2018. Hubungan Antara Kinerja Karyawan Dengan Promosi Jabatan Pada Unit Taman Marga Satwa Ragunan Dinas Kehutanan Provinsi DKI Jakarta. Akademi Sekretari dan Manajemen Bina Sarana Informatika Jakarta: Jakarta.

Solimun, 2018. Metode Penelitian Kuantitatif Perspektif Sistem. UB Press. Malang.

Wobowo, 2013. Manajemen Kinerja. Jakarta.

Wirawan. 2009. Evaluasi Kinerja Sumber Daya Manusia, Teori Aplikasi dan Penelitian. Salemba Empat, Jakarta. 